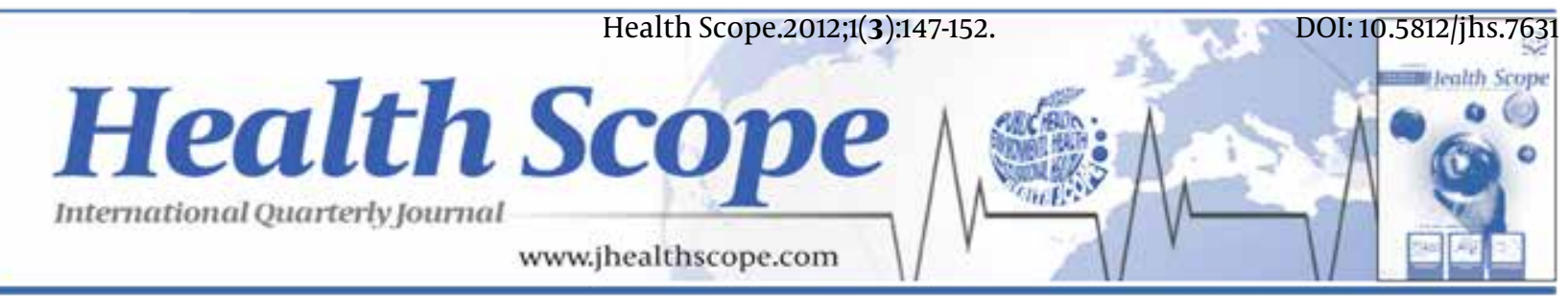

\title{
Management of Non-Revenue Water in Distribution Network and Conveyor Lines; a Case Study
}

\author{
Hosein Kamani ${ }^{1,3}$, Mohammad Malakootiann ${ }^{2}$, Mohammad Hoseini ${ }^{3^{3}}$, Jalil Jaafari ${ }^{3}$ \\ ${ }^{1}$ Health Promotion Research Center, Zahedan University of Medical Sciences, Zahedan, IR Iran \\ ${ }^{2}$ Environmental Health Research Center and Environmental Health Engineering Department, School of Public Health, Kerman University of Medical \\ Sciences, Kerman, IR Iran \\ ${ }^{3}$ Department of Environmental Health Engineering, School of Public Health, Tehran University of Medical Sciences, Tehran, IR Iran
}

\begin{tabular}{|c|c|}
\hline A R T I C L E I N F O & A B S T R A C T \\
\hline $\begin{array}{l}\text { Article type: } \\
\text { Research Article }\end{array}$ & $\begin{array}{l}\text { Background: The Non-Revenue water refers to a difference between the volume of water } \\
\text { entering the system and billed authorized consumption. }\end{array}$ \\
\hline $\begin{array}{l}\text { Article history: } \\
\text { Received: 07 Aug } 2012 \\
\text { Revised: } 23 \text { Aug } 2012 \\
\text { Accepted: } 26 \text { Aug } 2012\end{array}$ & $\begin{array}{l}\text { water in order to recognize the factors influencing water losses so that the information } \\
\text { gathered can used in Non-Revenue water reduction management. } \\
\text { Materials and Methods: Kazerun had been selected as a functional sample in this study. } \\
\text { This research was undertaken for one year in } 2010 \text { as a cross-sectional study. The method- } \\
\text { ology has been abstracted from International Water Association (IWA). }\end{array}$ \\
\hline $\begin{array}{l}\text { Keywords: } \\
\text { Water } \\
\text { Disease Management } \\
\text { Case Study }\end{array}$ & $\begin{array}{l}\text { Results: Around 12,995,619 m3 water was produced in Kazerun annually. The rate of Non- } \\
\text { Revenue water was estimated around 5,011,084 } \mathrm{m}^{3} \text {, representing } 38.56 \% \text { of the total vol- } \\
\text { ume of water produced. The highest proportion of Non-Revenue water in Kazerun was } \\
\text { related to real losses ( } 22.88 \% \text { ). The leakage rate was about } 10.46 \% \text { in distribution systems } \\
\text { and } 11.20 \% \text { in subscribers' networks that by themselves account for the highest percent- } \\
\text { age rate of real losses. The rate of apparent losses was about } 14.4 \% \text { and unbilled author- } \\
\text { ized consumption was about 1.3\%. } \\
\text { Conclusions: The Non-Revenue water showed a significant rate while compared with } \\
\text { similar studies. The high rate of real losses in Kazerun was mainly due to old-fashioned } \\
\text { pipeline network in distribution systems, invisible leakage, ground breakage and the } \\
\text { water pressure on the system. The high percentage of apparent losses can be modified } \\
\text { by improving polices as well as financial investment. }\end{array}$ \\
\hline
\end{tabular}

Implication for health policy/practice/research/medical education:

Non-revenue water (NRW) is one of the major issues affecting water utility in the developing countries and it has a particular obstacle in our country. NRW refers to difference between the amount of water put into the distribution system and the amount of water billed to consumers. The aim of this study was to investigate the amount of NRW and assessing its various components in Kazerun city, Fars, Iran based on International Water Association (IWA) methodology.

- Please cite this paper as:

Kamani H, Malakootian M, Hoseini M, Jaafari J. Management of Non-Revenue Water in Distribution Network and Conveyor Lines; a Case Study. Health Scope. 2012; 1 (3): 147-52.

\footnotetext{
${ }^{*}$ Corresponding author: Mohammad Hoseini, Department of Environmental Health Engineering, School of Public Health, Tehran University of Medical Sciences, Tehran, IR Iran. Tel:+9821-22909114, Fax:+9821-88954914,E-mail: m_hoseini2174@yahoo.com
} 


\section{Background}

Water plays as a vital and fundamental role in the health, hygiene and welfare of communities. The destinies of many societies and communities are affected by water and it will become much more important in the future $(1,2)$. Most countries located in dry and semi-dry regions around the world are facing serious threat to producible water shortage (3). Many parts of Iran suffer from this type of crisis as a result of limited and reduced precipitation, up-surging population growth resulting in increased water demands, huge volume of contaminated materials being dumped into water bodies, and the lack of producible water (4). Another reason of the shortage in producible water is the water losses from conveyor lines which are about three times the world standard or $15 \%$ of water produced (5). In view of the limited water sources in our country, conservation and careful management of this precious resource is of vital importance. The critical nature of these factors is both a local and global problem, but particularly so in developing countries. For that reason, all around the world, much consideration is given to the best exploitation of existing water sources, the issue of logical consumption and how best to control and reduce water losses in conveyor lines $(6,7)$. In answer to the water loss issues, the International Water Association (IWA) has standardized an index of unaccounted for water called "water format" and has presented new indicators in order to investigate and enable more efficient conveyor lines $(8,9)$.

Water losses are mainly occurred due to mismanagement of water sources (10). Factors that impact water losses are the pressure of water volume in the pipelines, the length of pipelines, distribution system complexity, expansion of distribution system, type of leakage control, observation of water standards in quality and quantity $(11,12)$. The IWA is following two main goals in unaccounted for water issues. Firstly providing international and standard items for real and apparent losses from balanced water, and secondly representing functional indicators to make international comparisons in conveyor lines losses (13). On the other hand, Water Balance is an analytical procedure that is able to provide water managers with factors influencing NonRevenue water using new technology. These procedures represent as key steps to be taken in strategic management in order to decrease the amount of Non-Revenue water. In summary, the main purpose of water balance is to recognize the indices impacting Non-Revenue water and investigate the effects of each factor, each of which should receive priority and be addressed in an effort to reduce Non-Revenue water (14-16). Generally, the water fed into a system is categorized into two sections as revenue and non-revenue water $(15,17)$. Revenue water refers to all authorized estimated or non-estimated consumption that is billable $(15$, 18). It would be the difference in the volume of water fed into the conveyor system and authorized consumption (17, $19,20)$. Generally, defining the unaccounted water refers to a difference in the volume of produced water and authorized consumption. In a current standard recommended by IWA, unaccounted water is replaced with non-revenue water. The non-revenue water, by itself, is divided into three categories: unbilled authorized consumption, apparent losses and real losses (18). Recognizing and assessing the rate and importance of each factor mentioned above, along with taking advantage of an efficient management system, will reduce non-revenue water loss resulting in an efficient water production system. So far, many studies have been carried out on assessment of water losses and non-revenue water in different parts of the world. Yeboah has been studied in the management of non-revenue water in the water supply of Accra, Ghana (22). Mutikanga et al. have assessed the apparent losses in urban water systems for Kampala city's distribution system using the standard IWA methodology (23).

\section{Objectives}

The intention of this work was to investigate the rate of non-revenue water and the factors influencing it in Kazerun city. Kazerun is located in the west of Fars province. It has mild winters and usually hot summers and is located in geographical coordinates of northern $29^{\circ}, 37^{\prime}$ longitude and $51^{\circ}, 39^{\prime}$ eastern latitude. It is $120 \mathrm{~km}$ from Shiraz, the center of Fars province in the south of Iran.

\section{Materials and Methods}

\subsection{Study Area}

This cross-sectional study was carried out in spring of 2010 in Kazerun in a bid to identify the rate of non-revenue water and the factors influencing it. At the 2006 census, the population of this city was 84,594 . The water of Kazerun is supplied by 13 wells and one spring. City has a daily total per capita water use of approximately $175 \mathrm{~L}$ (175 lpcd). In the water supply system the length of the conveyor line transmitting water to the city is about $37 \mathrm{~km}$ and in the distribution network, the length of pipelines aged less than 10 years, 10-20, 20-25 and more than 25 years is $81,112.5,54$ and $157.5 \mathrm{~km}$ respectively.

\subsection{Research Approach}

The methodology has been abstracted from IWA as shown in Figure 1 (8). Initially, the volume of water in Kazerun was measured using a flow meter. The required modifications and corrections in entering data were done at this stage. Then, the billed measured consumption, the billed unmeasured consumption, and the total volume of water sold to water and sewage distribution organizations were estimated. The revenue water is the sum of all the amounts mentioned above. When the revenue water is subtracted from to total volume of water produced, the non-revenue water is obtained. Additional non-revenue water such as water consumed in companies and factories was measured but not billed. The rate of authorized consumption was obtained from the total amount 
of billed authorized consumption and unbilled authorized consumption. The amount of water loss could be measured by subtracting the authorized water from the total amount of water entering in the system. To obtain the water loss indices, all water losses are divided into two parts: a) apparent losses and b) real losses $(8,22)$.

\subsection{Estimation of Apparent Losses}

To estimate the apparent losses, it is necessary to determine the unauthorized consumption, data management errors, and deficiency of measuring systems $(8,23)$. The apparent losses are the sum of all the indices mentioned above. In order to find out the unauthorized consumption, a door-to-door investigation was performed to determine the number of unauthorized subscribers and their rate of consumption. Data management errors included exploiting errors, management errors and staff errors (22). Losses due to these errors were estimated based on IWA approach demonstrated in references 22 and 23.

\subsection{Determination of Real Losses}

The real loss indices include leakages in the distribution mains, leakages in the on connections, leakages and over- flow at the utility's storage tanks. To determine the amount of leakage at utility's storage tanks in Kazerun, the inlet to and outlet from the tanks were stopped at night while the consumption rate was at its lowest point. In this way the fall in water level was determined and consequently the rate of leakage for the whole year was estimated. To determine any losses from water meters, meters classified based on their ages into meters with the age of less than 8 years, between 8 and 15 years and more than 15 years and 10\% of each class was inspected. All water meters studied in this work was multi-jet mechanical flow meters. To measure the water loss due to over-flows at the utility's storage tank, the number of times of each over-flow and the intervals was determined. The outcome of each over-flow and its relation to Bernoulli's law was obtained. Then the total outcome of each loss of over-flow was estimated by multiplying the number of times into intervals. Furthermore, the connection, distribution systems and conveyor lines' leakages were estimated by subtracting the leakage rate and overflows at the utility's storage tanks from the total volume of water loss. An investigation was conducted over the occurrences and the outcome of breakage, connection happenings, distribution systems and conveyor lines and all the water and wastewater organization events $(8,22)$.

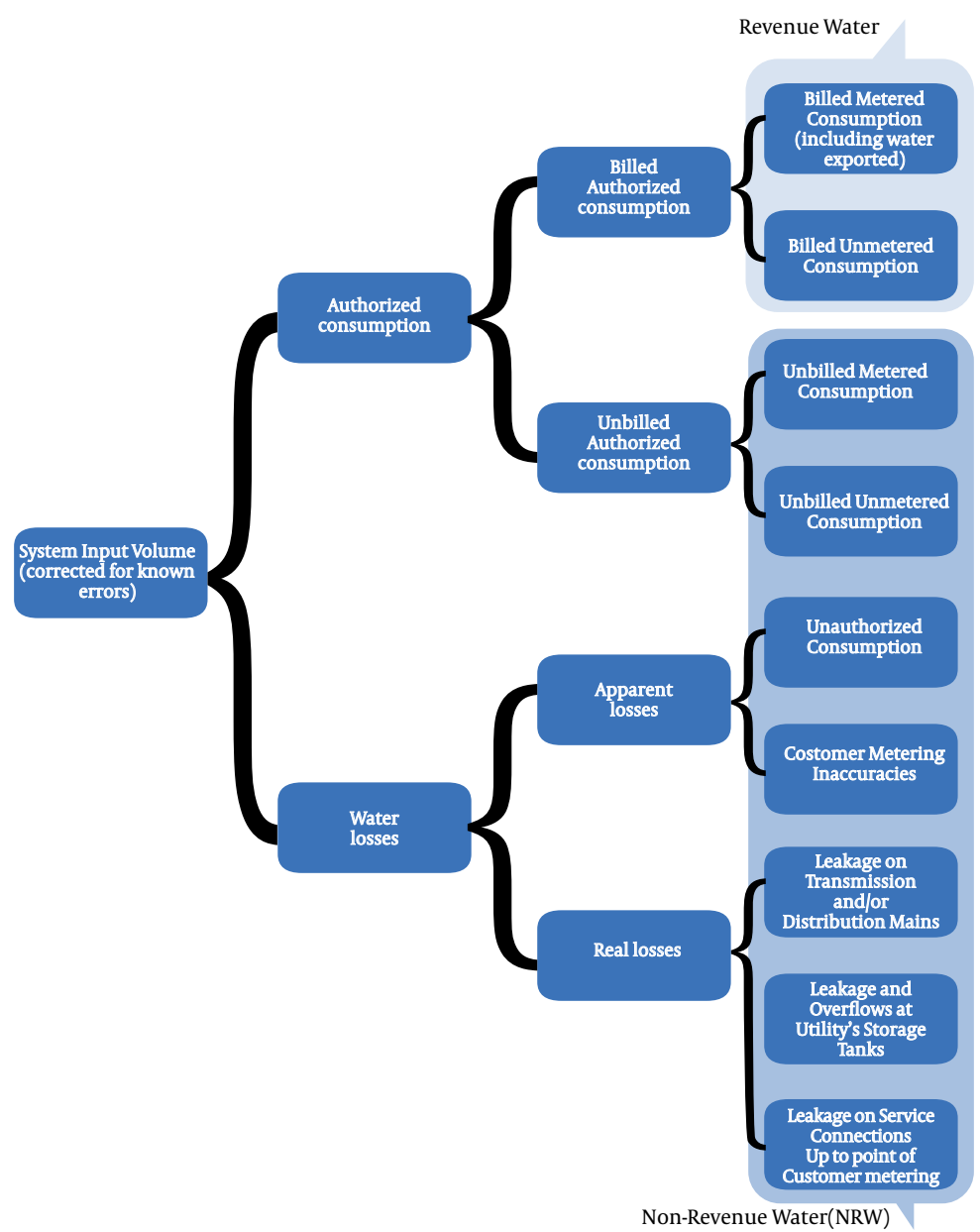

Figure 1. Step by Step Method Driven from IWA in Order to Assess NRW in Water Supply Systems 


\section{Results}

Based on data from the wells and spring suppliers, it was revealed that $85.16 \%$ of the city's water consumption is supplied by wells while $14.84 \%$ is accounted for by fountains. The percentage of non-revenue water and revenue water with their components had been shown in Tables (Table 1 and Table 2) respectively. Based on the results of this research, it was observed that the total amount of water loss, including real and apparent losses in both distribution systems and conveyor lines, is about $37.3 \%$ in Kazerun, as shown in the last row of Table 1. If the unbilled authorized consumption rate of $1.3 \%$ is added to $37.3 \%$, the total amount of non-revenue water becomes $38.6 \%$, which means that the total volume of non-revenue water is about $5,011,084 \mathrm{~m}^{3}$. (Figure 1 ) shows the percentage of revenue and non-revenue water. The highest percentage of non-revenue water was related to real losses of $22.88 \%$ in Kazerun. (Figure 2) shows the percentage of revenue and non-revenue water in Kazerun water supply system.

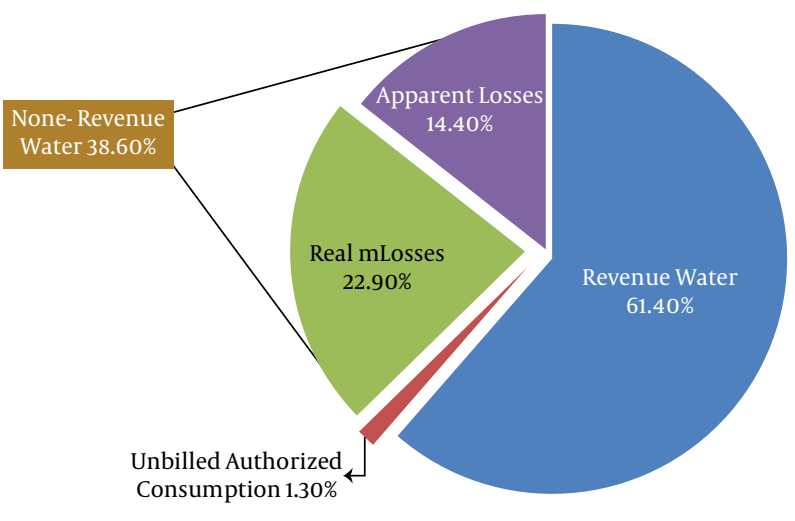

$\overline{\text { Figure 2. Comparison between Revenue and None Revenue Percentages }}$

\begin{tabular}{ll}
\hline Table 2. Components of Revenue Water and Their Percentages \\
\hline & $\begin{array}{l}\text { Billed Authorized Consumption, } \\
\text { No. }(\%)\end{array}$ \\
\hline $\begin{array}{l}\text { Water Delivery to } \\
\text { Other System }\end{array}$ & $61.40(3.86)$ \\
$\begin{array}{l}\text { Billed Metered Con- } \\
\text { sumption }\end{array}$ & $61.40(43.68)$ \\
$\begin{array}{l}\text { Billed unmetered } \\
\text { Consumption }\end{array}$ & $61.40(13.98)$ \\
\hline
\end{tabular}

\section{Discussion}

Based on the present results, the percentage of nonrevenue water revealed in this study was very high. These findings are very significant particularly since water shortages in Kazerun due to lack of water sources is also as a result of low annual precipitation (the annual average precipitation in Kazerun is $400 \mathrm{~mm}$ ). In comparison, in a city like Toronto where the average annual precipitation is a high of $788 \mathrm{~mm}$ and the rate of water loss is about $10 \%$, there is no water shortage in the city. Meanwhile, the average amount of unaccounted for water in different geographical regions in the United States is between 3.3 to $12.7 \%$, showing a considerably low rate compared to that of Iran (24). The non-revenue water in Trinidad and Tobago is up to $45 \%$ (22). In Vietnam it is estimated at about 50\%; close to the measurement found in Iran (25). Based on total volume of non-revenue water 5,011,084 $\mathrm{m}^{3}$, and with the average price of $1 \mathrm{~m}^{3}$ of water in Kazerun at US\$0.136 (estimated at the year of study), the company is losing US\$69,038 annually. The amount of leakage in distribution systems accounts for $10.46 \%$ and that in conveyor lines is $1.12 \%$ due to wear in the distribution systems, invisible leakages, ground breakages and high pressure as a result of the high volume of water (22). Studies show that in Serbia, real losses are estimated about 36\% (26). The reconstruction, and repair and renewal of distribution systems and conveyor lines will play an important role

\begin{tabular}{|c|c|c|c|c|c|c|}
\hline & Percent & $\begin{array}{l}\text { Authorized } \\
\text { Consumption }\end{array}$ & Real Losses & Apparent Losses & Total losses & $\begin{array}{l}\text { Non-revenue } \\
\text { water }\end{array}$ \\
\hline Unbilled Metered Consumption & 0.28 & 1.30 & - & - & & \\
\hline $\begin{array}{l}\text { Unbilled Unmetered Consump- } \\
\text { tion }\end{array}$ & 1.03 & 1.30 & - & - & & \\
\hline Leakage on Distribution Mains & 10.46 & - & 22.90 & - & & \\
\hline Leakage on Transmission Mains & 1.12 & - & 22.90 & - & & \\
\hline Overflow at utility's Storage Tank & 0.02 & - & 22.90 & - & & \\
\hline Leakage on Utility's Storage Tank & 0.099 & - & 22.90 & - & & \\
\hline $\begin{array}{l}\text { Leakage from Household Plumb- } \\
\text { ing }\end{array}$ & 11.20 & - & 22.90 & - & & \\
\hline Unauthorized Consumption & 3.21 & - & - & 14.40 & & \\
\hline Management and Staff Error & 2.04 & - & - & 14.40 & & \\
\hline \multirow[t]{2}{*}{ Metering Inaccuracies } & 9.15 & - & - & 14.40 & & \\
\hline & & & & & 37.30 & 38.60 \\
\hline
\end{tabular}


in reducing real water losses. Control in the pressure of the pipeline network is among other suitable solutions to control losses as a result of leakage in the distribution systems and conveyor lines $(22,27)$. Even the intervals of customer connection and breakage in the pipelines can be regarded as a function of network pressure. Therefore, network pressure management is considered as a basic and the most essential factor in non-revenue water controlling strategy $(8,28,29)$. The experiences and results of other countries such as South Africa show that by programming and controlling the unaccounted water, it decreased that amount from $66 \%$ to $22 \%$ in 18 months (30). Dilapidated and damaged meters coupled with the low accuracy in recording small flows and starting outputs are the most important factors accounting for the apparent losses which were estimated at 9.15\%. It is recommended that a novel generation of mechanical meters be installed that can be read from a remote distance. These new meters are designed in such a way that other parts can be installed on them so that they can function as meters $(8,31)$. Based on the results, the unauthorized consumption is accounted for $3.21 \%$ of total amount of entering water into the system. It is recommended to take necessary measures to recognize these consumers, providing their files in the organization and issuing a bill for them. $1.32 \%$ of total amount of water is accounted for unbilled authorized consumption including other companies and organizations consumption that are measured but no bills are issued. Consequently, no money could be obtained. Even firefighting faucets and local faucets that demand that steps are taken in order to economize the water consumed in these sections.

As a conclusion, it was found that in real losses, the main factor affecting non-revenue water was leakage from distribution network, so the non-revenue water could be considerably reduced by repairing the network, identifying and repairing the leakages and breakages and taking advantage of a suitable management system in controlling the water pressure. In apparent losses, the most important crucial factor is accounted for deficiency in measuring apparatus (9.15\%) such as dilapidated meters, damaged or out of order meters, and low accuracy in recording the least and starting outputs. Therefore, installation of new meters can reduce non-revenue water in the system. It is recommended to install new generation mechanical meters that can be read from a remote distance. Although the installation of these meters is expensive, the long term economic benefit having made more water available is much higher than the cost of controlling the losses or producing the same amount of water.

\section{Acknowledgments}

We would like to state our profound gratitude to all staff of Kazerun Water and Sewage Organization whose support and help played a vital role throughout this study.

\section{Acknowledgments}

None declared.

\section{Authors' Contribution}

All authors have worked equally to prepare this paper.

\section{Financial Disclosure}

None declared.

\section{Funding/Support}

None declared.

\section{References}

1. Hofkes H. Small Community Water Supplies: Technology of Small Water Supply Systems in Developing Countries. New York: John Wiley \& Sons; 1984

2. Knight CG, Velev SB, Staneva MP. The emerging water crisis in Bulgaria. GeoJournal.1995;35(4):415-23.

3. Frauendorfer R, Liemberger R. The Issues and Challenges of Reducing Non-Revenue Water. Asian Development Bank; 2010.

4. Paykary M, Mehrabani A. [Water Treatment Fundamental]. Esfahan: Arkan publication; 2005.

5. Nokhah F, Azhari N, editors. Analysis of unaccounted for water in Ardabil province in base of regulation of water balancing form. The first national conference on utilization of water and wastewater; 2005; Tehran, Iran.

6. Beare S, Bell R, Fisher B. Determining the Value of Water: The Role of Risk, Infrastructure Constraints, and Ownership. Amer J Agr Econ. 1998;80:916-40.

7. Shamir U, Howard C. Editorial. J of Water Res Pla and Manage. 2000;126(3):114-17.

8. Lambert A, Hirner W. Losses from water supply system: Standard Terminology and recommended performance measures. Voda $i$ sanitarna tehnika. 2002;32(1):29-38.

9. McKenzie R, Seago C. Assessment of real losses in potable water dis tribution systems: some recent developments. London, ROYAUMEUNI: International Water Association; 2005.

10. Tothova K, Dubova V, Barlokova K, editors. Water Losses in the Distribution of Drinking and Service Water in Industry. 8th International Conference on Water; 2004; Czech Republic. Zlin.

11. Lambert A. Accounting for Losses: The Bursts and Background Concept. Water and Environment Journal. 1994;8(2):205-14.

12. Islam MS, Sadiq R, Rodriguez MJ, Francisque A, Najjaran H, Hoorfar M. Leakage detection and location in water distribution systems using a fuzzy-based methodology. Urban Water J. 2011;8(6):351-65.

13. Lamber A, Brown T, Takizawa M, Weimer D. A review of performance indicators for real losses from water supply systems. Water SRT-Aqua. 1999;48:227-37.

14. Alegre H, Hirner JM, Baptista JM, Parena R, International Water A Iwa. Performance indicators for water supply services. London: IWA Publishing; 2000.

15. González-Gómez F, García-Rubio MA, Guardiola J. Why Is Nonrevenue Water So High in So Many Cities? INTJ WATER RESOUR D. 2011;27(2):345-60.

16. Almandoz J, Cabrera E, Arregui F, Cobacho R. Leakage Assessment through Water Distribution Network Simulation. INTJ WATER RESOUR D. 2005;131(6):458-66.

17. Farley M, Trow S. Losses in water distribution networks: a practitioner's guide to Assessment Monitoring and control. Water science and Technology: Water Supply. London: IWA Publishing Inc; 2003.

18. Mckenzie RS, Lambert A, Kock JE. Benchmarking of leakage for water supplies in South Africa: user guide for the bench leak model. South Africaan Water Research Commission; 2002. 
19. Bridges G, Macdonald M. Leakage Control - the Neglected Solution? 20th WEDC Conference Affordable water supply and sanitation; 1994; Colombo, Sri Lanka.; 1994.

20. Lavee D. The effect of water supply uncertainty on farmers choice of crop portfolio. Agri Water Manage. 2010;97(11):1847-54.

21. Seago C, Bhagwan J, McKenzie R. Benchmarking leakage from water reticulation systems in South Africa. Water SA Association of Crop Science, Uganda; 2007.

22. Yeboah P. Management of non-revenue water: a case study of the water supply in Accra, [dissertation]. Ghana: Loughborough University; 2008.

23. Mutikanga HE, Sharma SK, Vairavamoorthy K. Assessment of apparent losses in urban water systems. Water Environ $J$ 2011;25(3):327-35.

24. F. VdL. The water encyclopedia. J Chemic Edu.1991;68(2):A48.

25. Trung DQ, Snow R, Doukas L, Tanh N, Trung N. Water loss reduction program in Vietnam. 24th WEDC Conference; 1998; Islam- abad, Pakistan.; 1998

26. Radivojevic D, Milicevic D, Petrovic N. I-WA best practice and performance indicators for water utilities in Serbia - Case Study PIROT. Arch Civil Eng. 2008;6(1):37-50.

27. Walski T, Bezts W, Posluszny E. Modeling leakage reduction through pressure control. AWWA. 2006;98:147-55.

28. Farley M, Liemberger R. Developing a non-revenue water reduction strategy, planning and implementing the strategy. Water Suppl J. 2005;5(1):41-50.

29. Orhan A, Eyduran E, Ozdem T. The method of leakage policy development. J Appl Sci Res. 2006;2(4):239-41.

30. R. R-J. Unaccounted- for water management in Kwazulu Natal. S. Africa. 29th WEDC international conference; 2003; Abuja, Nigeria.; 2003.

31. Michelsen AM, McGuckin JT, stumpf d. nonprice water conservation programs as a demand management tool1. jawra Journal of the American Water Resources Association. 1999;35(3):593-602. 